\title{
Effect of cold storage on the performance of Trichogramma bourarachae (Pintureau and Babault) (Hymenoptera: Trichogrammatidae)
}

\author{
Khaled Abbes', Anis Zouba², Ahlem Harbi ${ }^{1,3}$ and Brahim Chermiti ${ }^{1 *}$
}

\begin{abstract}
In Tunisia, the use of the egg parasitoid trichogrammatid wasps to cope with several economic pests is gaining increasing attention. Trichogramma bourarachae (Pintureau \& Babault) is among the Trichogramma wasps naturally present in Tunisia and regarded as a potential natural enemy to be used in biological control programs of many lepidopteran pests that cause economic losses. The propensity of T. bourarachae to cold storage with and without diapause induction was studied. The effect of this technique on its emergence rate and parasitic activity was investigated. The study showed that wasps of T. bourarachae treated at the induction temperature of $15^{\circ} \mathrm{C}$ for 5 days can be stored at $4 \pm 1{ }^{\circ} \mathrm{C}$ for more than 30 days without significant loss of their performances. By using this prestorage temperature, T. bourarachae could keep its emergence capacity (77.5\%) up to 60 days of cold storage at $4 \pm 1{ }^{\circ} \mathrm{C}$. However, its parasitic activity decreased significantly (37.16\%) after 45 days of cold storage. These results are promising for its mass production, transport, and release in the framework of national campaigns to control several agricultural pests of economic importance.
\end{abstract}

Keywords: Egg parasitoid, Trichogramma bourarachae, Cold storage, Parasitoid performance

\section{Background}

Trichogramma species (Hymenoptera: Trichogrammatidae) are among the most common natural enemies of several insect pests. They are used worldwide in biological control programs because of their ability to parasitize eggs of many economic lepidopterous pests of cultivated plants and their relatively easy mass rearing (Hassan, 1993). They have been used to treat millions of hectares of agricultural crops and forests against diverse insect pests (Li, 1994). In Tunisia, the use of trichogrammatid wasps is gaining increasing attention as they become officially used in the framework of national campaigns of integrated control of several economic

\footnotetext{
* Correspondence: chermiti54@yahoo.fr

'Department of Plant Protection and Biological Sciences, High Agronomic

Institute of Chott-Mariem, University of Sousse, Sousse, Tunisia

Full list of author information is available at the end of the article
}

pests such as the carob moth Ectomyelois ceratoniae (Zeller), the pomegranate moth Virachola livia (Klug), and the invasive South American leaf miner Tuta absoluta (Meyrick). Among Trichogramma wasps naturally present in Tunisia, Trichogramma bourarachae (Pintureau \& Babault) was reported in May 2002 in olive (Olea europaea L.) groves located in the region of Sfax (South East of Tunisia) (Herz et al., 2007). In 2010, it was also reported for the first time in the oases of the South Western Tunisia parasitizing eggs of $T$. absoluta and the carob moth E. ceratoniae. It is an abundant species in the Mediterranean area (Herz et al., 2007) and regarded as a potential natural enemy to be used in biological control programs of many lepidopterous economic crop pests.

Inundative releases of Trichogramma species as a biological control agents require their mass production 
(Tezze and Botto, 2004). Furthermore, release sites are often far from rearing facilities and these facilities are very scarce. Therefore, the development of adapted techniques of production, release, and storage is crucial to guarantee the flexibility, the profitability, and the efficiency of their mass rearing and to ensure their availability in sufficient numbers at the time of their release in the field (Leopold, 1998; Tezze and Botto, 2004; Ayvaz et al., 2008; and Lü et al., 2019). In particular, the cold storage technique which, in most cases, allows to delay wasps' eclosion without compromising their performance was studied for several Trichogramma species (Bradley et al., 2004; Ozder and Saglam, 2004; and Kumar et al., 2005) as it is important to investigate its effects on their biological performances and their propensity to cold storage (Tezze and Botto, 2004). Two main cold storage techniques have been used in mass rearing of Trichogramma spp., with and without diapause induction depending on the desired storage period and their sensitivity to diapause induction (Greenberg et al., 1996). Mass rearing of cold storage-adapted species can ensure high-quality parasitoids and contribute in reducing production and transport costs, while synchronizing releases of natural enemies with pest occurrence (Pitcher et al., 2002 and Colinet and Boivin, 2011).

In this context, the aim of this research was to study the ability of $T$. bourarachae to cold storage with and without diapause induction and to investigate the effects of this technique on its emergence rate and parasitic activity.

\section{Materials and methods}

\section{Insect rearing}

Adults of $T$. bourarachae used in this study were obtained from a laboratory colony, initially started with individuals collected in 2010 from parasitized eggs of T. absoluta infesting open filed tomato crops in the oases of Tozeur located in the South West of Tunisia. The parasitoid strain has been reared for many generations in the laboratory of entomology of the Technical Center of Dates (TCD) under controlled conditions at $25 \pm 1{ }^{\circ} \mathrm{C}, 70 \pm 5 \% \mathrm{RH}$ and 16:8 (L:D) photoperiod on eggs of Ephestia kuehniella Zeller (Lepidoptera: Pyralidae) as a factious host. E. kuehniella eggs were obtained from a laboratory rearing of the moth maintained on semolina under the same climatic conditions used for the wasp.

\section{Effect of cold storage on $T$. bourarachae}

Pieces of a white card $(1 \times 5 \mathrm{~cm})$, containing one hundred fresh host eggs of E. kuehniella (<1-day old), fixed with Arabic gum diluted to $30 \%$, were placed separately in glass tubes $(6 \mathrm{~cm}$ in length $\times 1 \mathrm{~cm}$ in diameter) for $24 \mathrm{~h}$ with newly emerged $T$. bourarachae wasps (1-day old) under standard rearing conditions $\left(25 \pm 1{ }^{\circ} \mathrm{C}\right.$ and 16:8 L:D photoperiod). Each glass tube contained a droplet of honey solution to provide parasitoids with carbohydrates. After $24 \mathrm{~h}$, adult parasitoids were removed from glass tubes. Carton cards containing the parasitized eggs were kept under standard rearing conditions until they reached the blackened stage (6th day). Three different cold storage procedures were tested: direct cold storage at $4 \pm 1{ }^{\circ} \mathrm{C}$ without diapause induction (prestorage), prestorage at $10^{\circ} \mathrm{C}$ for 5 days, followed by cold storage at $4 \pm 1{ }^{\circ} \mathrm{C}$ and prestorage at $15^{\circ} \mathrm{C}$ for 5 days, followed by cold storage at $4 \pm 1{ }^{\circ} \mathrm{C}$. The photoperiod used for the prestorage of parasitoids was L8:D16 because Trichogramma diapauses under short day length (Pizzol, 1978). Afterwards, the egg cards were stored for $0,15,30,45$, and 60 days at $4 \pm 1{ }^{\circ} \mathrm{C}$ in a refrigerator in a complete darkness. Similar temperatures (around $4{ }^{\circ} \mathrm{C}$ ) were used for the cold storage of other Trichogramma species (Ventura Garcia et al., 2002; Ma and Chen, 2006; and Ayvaz et al., 2008). Fifty egg cards were randomly assigned to each storage period for each cold storage procedure. At the end of each storage period, 10 randomly selected egg cards for each cold storage procedure were transferred into an incubator and maintained at standard rearing conditions $\left(25 \pm 1{ }^{\circ} \mathrm{C}\right.$ and 16:8 L:D photoperiod) until the emergence of adult parasitoids.

The emergence rate was determined by dividing the number of parasitized eggs presenting emergence holes by the total number of parasitized eggs as a percentage for each tested cold storage procedure, for each storage period, and for each egg card. The impact of the cold storage procedures tested and the cold storage period on the performance of $T$. bourarachae females was studied as described by (Pizzol et al., 2010) with slight modifications. For each cold storage procedure and each cold storage period, 30 females (24-h old) were used to assess the parasitism and the mortality rates during the first 7 days after their emergence. Female parasitoids were individually isolated in glass tubes $(6 \mathrm{~cm}$ in length, $1 \mathrm{~cm}$ in diameter) containing a carton card with 100 eggs of E. kuehniella and a droplet of honey solution as a food source. The egg cards were daily replaced by fresh ones for 7 days, and parasitized eggs were allowed to develop at $25^{\circ} \mathrm{C}$ and a $14: 10 \mathrm{~L}: \mathrm{D}$ photoperiod. The number of parasitized eggs and the number of dead females during the first 7 days after their emergence were determined. Furthermore, the reduction in parasitization of $T$. bourarachae on E. kuehniella eggs was estimated as a function of cold storage procedure and cold storage period (Siam et al., 2019).

\section{Data analyses}

Data sets were first tested for normality and homogeneity of variance using Kolmogorov Smirnov D test and Cochran's test, respectively. The effects of cold storage 
procedure, of cold storage period, and potential interactions between these 2 factors on the emergence rate and parasitism rate of the wasp were estimated. For this, a factorial ANOVA was used. Subsequently, additional one-way ANOVA, followed by Duncan post hoc test for multiple comparisons inside the different cold storage procedure and cold storage period sub-datasets were carried out. All statistical analyses were performed using $R$ project for statistical computing (R Core Team, 2019).

\section{Results and discussion}

The statistical analysis results are summarized in Table 1. The emergence rate of $T$. bourarachae adults varied significantly among cold storage procedures tested (significant cold storage procedure factor) and cold storage periods assessed (significant cold storage period factor). However, there was non-significant interaction between the cold storage procedure and cold storage period factors, i.e., cold storage procedure affects the emergence rate of the wasp the same way among cold storage periods. Concerning the parasitism rate ensured by $T$. bourarachae, it varied significantly among cold storage procedures tested (significant cold storage procedure factor) and cold storage periods assessed (significant cold storage period factor). Besides, there was a significant interaction between the cold storage procedure and cold storage period factors on the parasitism rate, i.e., cold storage procedure affects the parasitism rate of the wasp differently among cold storage periods.

The highest mean emergence rate $(88.3 \%)$ was observed when $T$. bourarachae pupae were cold stored directly at $4 \pm 1{ }^{\circ} \mathrm{C}$. Lower mean emergence rate (87.0\%) was observed when pupae were subjected to prestorage period at $15^{\circ} \mathrm{C}$, while the lowest mean emergence rate (84.7\%) was obtained when wasps were subjected to prestorage period at $10^{\circ} \mathrm{C}$ (Fig. 1). Concerning the effect of the storage period, overall, the emergences rate of $T$. bourarachae decreased when the storage period increased. Statistically similar emergence rates were observed after 0 and 15 days of conservation (93.8 and
92.6\%) at $4 \pm 1{ }^{\circ} \mathrm{C}$ with, respectively. Lower emergence rates of $87.56,82.36$, and $77.00 \%$ were observed after 30 , 45 and 60 days, respectively, of conservation at $4 \pm 1{ }^{\circ} \mathrm{C}$ (Fig. 1).

Parasitization of $T$. bourarachae on E. kuehniella eggs decreased with increasing of storage period (Fig. 2). The highest parasitization values were obtained by adults emerged from the pupae, which were not cold stored (0 days) and without statistical differences among all tested procedures with parasitism rates ranging from $56.86 \pm$ 1.53 to $60.36 \pm 1.41$ eggs/female. The highest parasitization values after 15 days of cold storage were $44.26 \pm 1.57$ and $40.83 \pm 1.82$ eggs/female ensured by adult wasp emerged from pupae subjected to a prestorage period at $15^{\circ} \mathrm{C}$ and direct storage respectively without statistical differences. Whereas, significantly lower parasitization value of $31.86 \pm 1.43$ eggs/female was observed by wasps subjected to a prestorage period in $10^{\circ} \mathrm{C}$. Statistically similar parasitization values were observed after 30 and 45 days of cold storage for wasps emerged from pupae subjected to prestorage period at $15^{\circ} \mathrm{C}$. After 60 days of cold storage, parasitism activity was very low not exceeding 7 eggs/female in all evaluated storage procedures (Fig. 2).

Prolonged low temperature had a detrimental effect on the survival of $T$. bourarachae emerged from coldstored pupae (Fig. 3). Mortality rates on the 7th day after adult's emergence increased substantially with increasing cold storage period, especially starting from day 15 using all storage procedures. Consequently, the estimated reduction in parasitization of $T$. bourarachae on E. kuehniella eggs varied as a function of cold storage procedure and cold storage period. The lowest parasitization reduction (39.64\%) was observed at 0 days of direct storage, while the highest (95.37\%) was noted after 60 days of storage, using the prestorage period of $15{ }^{\circ} \mathrm{C}$ (Table 2). The highest mortality rate was registered after 60 days of cold storage in female wasp subjected to prestorage period at $10^{\circ} \mathrm{C}$. Lower mortality rates of 56.67 and $50 \%$ were observed when

Table 1 Results of factorial ANOVA used to analyze the emergence rate and the parasitism rate of T. bourarachae on E. kuehniella eggs as function of cold storage procedure, cold storage period, and their interaction

\begin{tabular}{llll}
\hline Source of variation & Degrees of freedom & $F$ & $p$ value \\
\hline Emergence rate & & 16.199 & $<0.001^{* * *}$ \\
Cold storage procedure & 2 & 145.377 & $0.001^{* * *}$ \\
Cold storage period & 4 & 0.648 & 0.736 \\
Cold storage procedure $\times$ cold storage period & 8 & 100.48 & $<0.001^{* * *}$ \\
Parasitism rate & & 460.11 & $<0.001^{* * *}$ \\
Cold storage procedure & 2 & $24.92<$ & $<.001^{* * *}$ \\
Cold storage period & 4 & 8 & \\
Cold storage procedure $\times$ cold storage period & 8 & &
\end{tabular}




\section{Direct storage $\square$ Prestorage $15^{\circ} \mathrm{C} \quad \square$ Prestorage $10^{\circ} \mathrm{C}$}

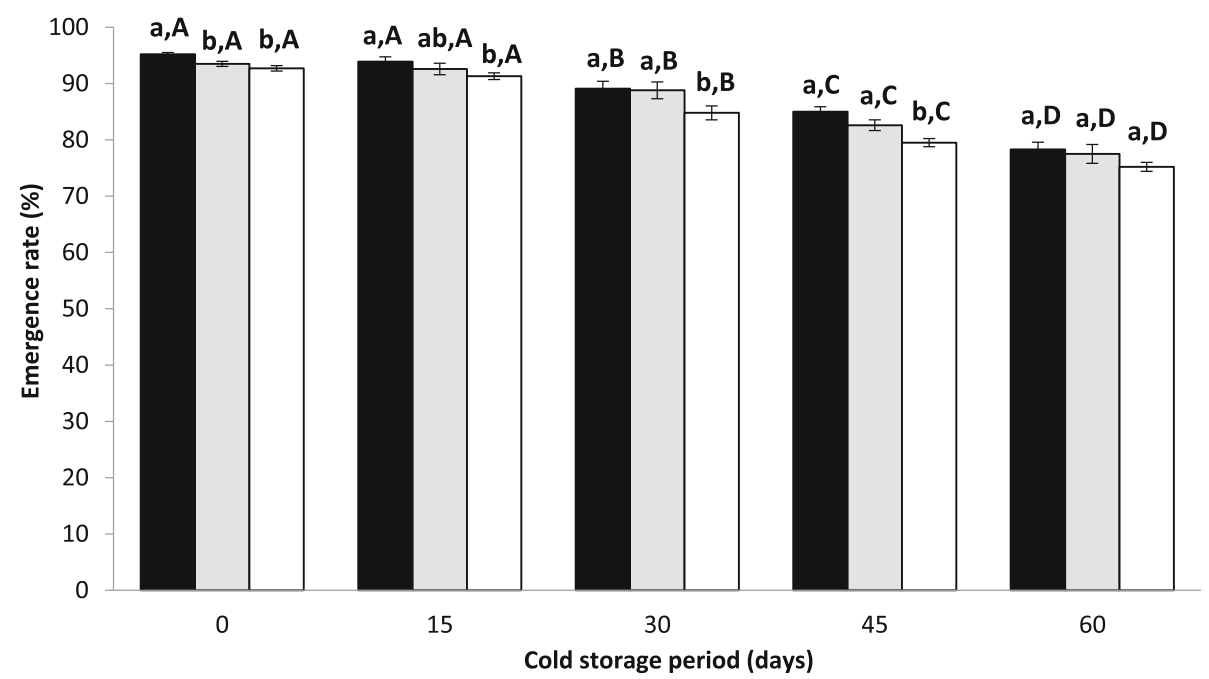

Fig. 1 Emergence rates of T. bourarachae after no or 5 days prestorage period at $10^{\circ} \mathrm{C}$ and $15^{\circ} \mathrm{C}$, followed by cold storage at $4 \pm 1{ }^{\circ} \mathrm{C}$ for 0,15 , 30, 45, and 60 days. (For the same cold storage period, similar lower-case letters indicate statistically similar emergences rates. For the same cold storage procedure, similar upper-case letters indicate similar emergences rates.)

females were not subjected to prestorage period and prestored at $15^{\circ} \mathrm{C}$ correspondingly (Fig. 3).

This study showed that $T$. bourarachae pupae are amenable to cold storage. However, prolonged cold storage periods can affect the rate of the emerged adults, as well as their parasitic ability. A reduction in the emergence rate due to the cold storage was also found with T. nerudai (Tezze and Botto, 2004) and T. cordubensis (Ventura Garcia et al., 2002). Similarly, a significant decline in parasitoid emergence rate was also reported by
Ozder and Saglam (2004) for T. brassicae and T. evanescens after storage at $4{ }^{\circ} \mathrm{C}$ for 3 weeks. The emergence rate of the Tunisian strain of $T$. bourarachae stored for 60 days at $4{ }^{\circ} \mathrm{C}$ without prestorage treatment $(78.3 \%)$ was higher than that reported for T. nerudai and T. cordubensis when they stored at $3-4{ }^{\circ} \mathrm{C}$ for 50 and 60 days, respectively (Ventura Garcia et al., 2002; and Tezze and Botto, 2004). For almost all periods of cold storage, the emergence rates were similar for adults emerged from pupae treated at the induction temperatures 10 and

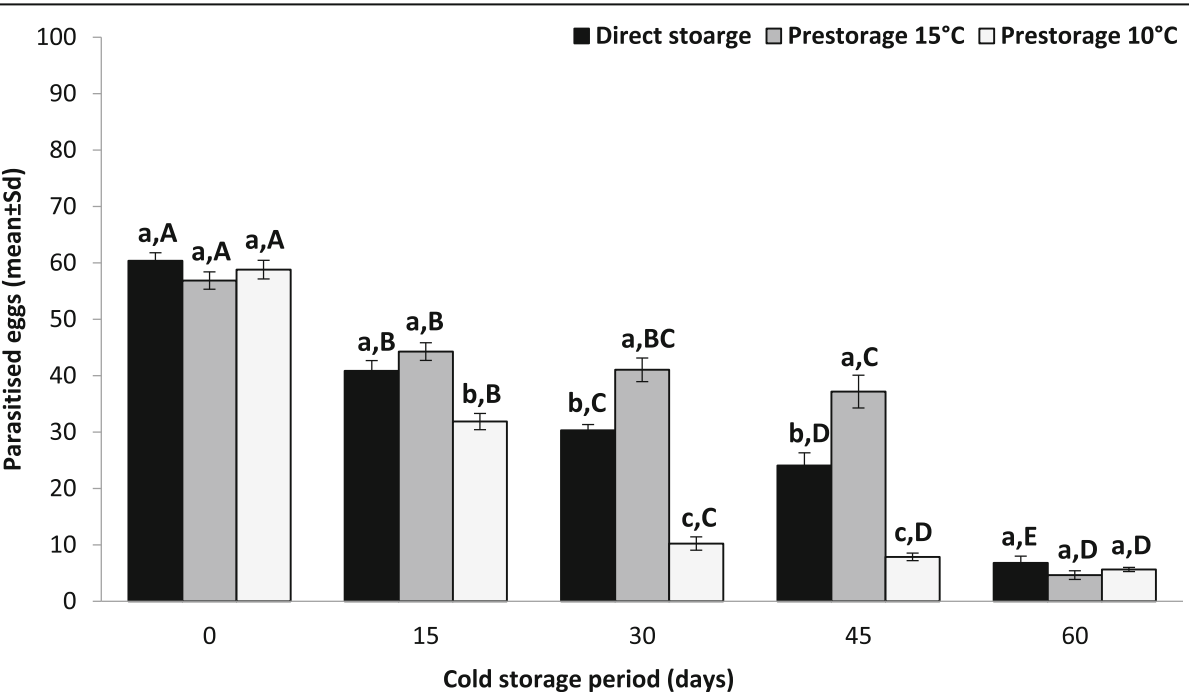

Fig. 2 Number of parasitized eggs of E. kuehniella by T. bourarachae after no or 5 days prestorage period at $10^{\circ} \mathrm{C}$ and $15^{\circ} \mathrm{C}$, followed by cold storage at $4 \pm 1^{\circ} \mathrm{C}$ for $0,15,30,45$, and 60 days. (For the same storage period, similar lower-case letters indicate statistically similar values. For the same storage procedure, similar upper-case letters indicate similar values.) 


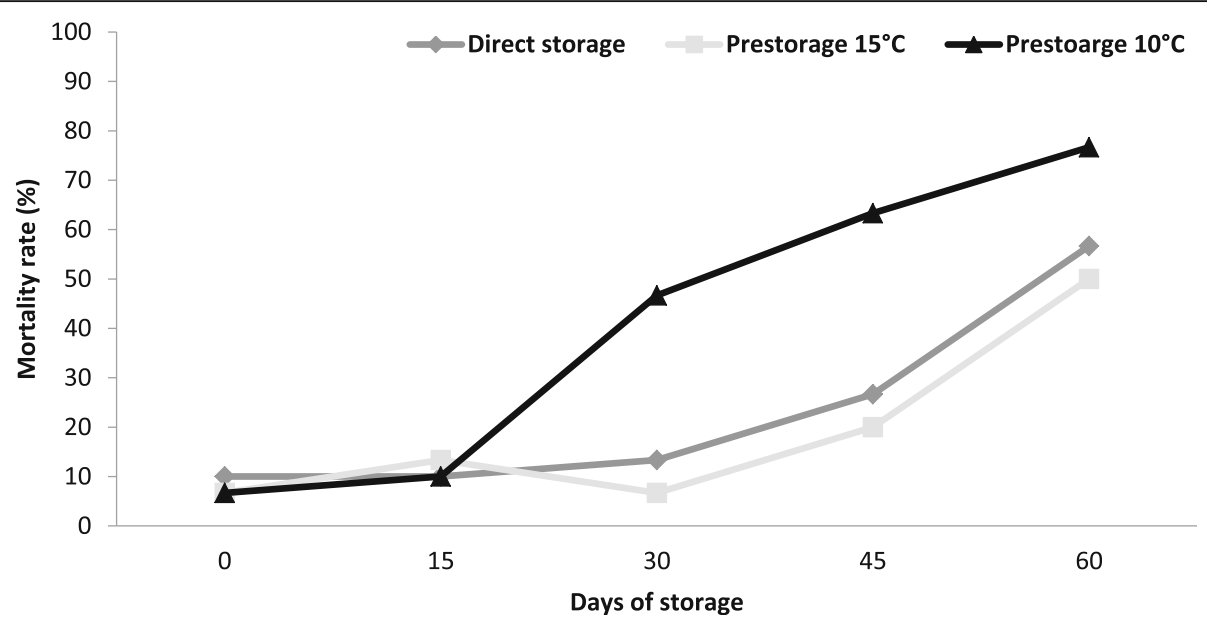

Fig. 3 Mortality rates of T. bourarachae females recorded after 7 days of their emergence after no or 5 days of exposure to $10^{\circ} \mathrm{C}$ and $15^{\circ} \mathrm{C}$, followed by storage at $4 \pm 1^{\circ} \mathrm{C}$ for $0,15,30,45$, and 60 days

$15^{\circ} \mathrm{C}$ and for those stored directly at $4 \pm 1{ }^{\circ} \mathrm{C}$. This was noted in the case of study of Pizzol et al. (2010) who found that the induction temperature $15^{\circ} \mathrm{C}$ was more favorable than $10^{\circ} \mathrm{C}$ in terms of emergence rate of $T$. cacoeciae adults after prolonged periods of cold storage.

In the present study, stored parasitoids emerged 1 day later than in the control group and developmental time from pupa to adult emergence was 5 days for all the samples in the control group and 6 days for all the samples in each of the treatments. According to Tezze and Botto (2004), this difference could be due to the delay of normal metabolic activity after being cold stored for a prolonged period. Such a small difference of one more day in the developmental time is not very significant in mass rearing programs (Tezze and Botto, 2004).

Prolonged low temperature affected the longevity of $T$. bourarachae emerged from stored pupae. However, the percentage of survived parasitoid on the 7th day after adults' emergence remained high, when pupae were subjected to the prestorage of $15^{\circ} \mathrm{C}$ and stored for 45 days at $4 \pm 1{ }^{\circ} \mathrm{C}$. This finding corroborates with those of Jalali and Singh (1992) who reported that longevity of $T$. achaea Nagaraja and Nagarakati, T. chilonis Ishii, and T. japonicum Ashmead declined after cold storage for 2 weeks at $2-5^{\circ} \mathrm{C}$.
In the present study, the parasitic ability of $T$. bourarachae females stored directly at $4 \pm 1{ }^{\circ} \mathrm{C}$, without prestorage treatment, decreased with increasing the storage period beyond 30 days. A reduction in the parasitic ability due to the direct cold storage was also reported by Ayvaz et al. (2008) for T. evanescens. However, Piao et al. (1992) found no difference in post-storage parasitism rate for $T$. dendrolimi Matsumura females stored for up to 30 days at $3-5^{\circ} \mathrm{C}$.

Obtained data showed that $T$. bourarachae pupae prestored at the induction temperature of $15^{\circ} \mathrm{C}$ can be cold stored at $4 \pm 1{ }^{\circ} \mathrm{C}$ up to 30 days without much loss of performance. Despite some decrease in the parasitism rate of the adults emerged from pupae treated at $15^{\circ} \mathrm{C}$ and stored for 45 days at $4 \pm 1{ }^{\circ} \mathrm{C}$, the mean number of parasitized eggs was high (37 parasitized eggs/female). Similar results were reported for T. cacoeciae by Pizzol et al. (2010) with the difference that the induction temperature of $10^{\circ} \mathrm{C}$ was better than $15^{\circ} \mathrm{C}$ in preserving the parasitic ability of the wasp after prolonged periods of cold storage.

\section{Conclusion}

The best procedure for $T$. bourarachae strain to be cold stored was by diapause induction at $15^{\circ} \mathrm{C}$, followed by a

Table 2 Estimated reduction in parasitization (\%) of T. bourarachae on E. kuehniella eggs as function of cold storage procedure and cold storage period

\begin{tabular}{llll}
\hline Cold storage periods (day) & Direct storage & Prestorage $10^{\circ} \mathrm{C}$ & Prestorage $15^{\circ} \mathrm{C}$ \\
\hline 0 & 39.64 & 41.2 & 43.14 \\
15 & 59.17 & 68.14 & 55.74 \\
30 & 69.7 & 89.77 & 58.77 \\
45 & 75.94 & 92.14 & 62.84 \\
60 & 93.2 & 94.37 & 95.37 \\
\hline
\end{tabular}


cold storage at $4 \pm 1{ }^{\circ} \mathrm{C}$ up to 30 days. This cold storage procedure allowed high emergence rates of the wasp and satisfactory parasitism rates. Mass rearing and releases of the wasp can greatly contribute to controlling several economic agricultural pests in Tunisia.

\section{Abbreviation \\ TCD: Technical Center of Dates}

\section{Acknowledgements}

We are thankful to the technicians of the laboratory of the entomology of the Centre Technique des Dattes for their help in the rearings.

\section{Authors' contributions}

$\mathrm{BC}$ designed the experiment, $\mathrm{AZ}$ conducted the essay, and $\mathrm{KA}$ and $\mathrm{AH}$ analyzed the data and wrote the manuscript. All authors read and approved the final manuscript.

\section{Funding}

Not applicable.

\section{Availability of data and materials}

The datasets used and/or analyzed during the current study are available from the corresponding author on reasonable request.

\section{Ethics approval and consent to participate}

Not applicable.

\section{Consent for publication}

Not applicable.

\section{Competing interests}

The authors declare that they have no competing interests.

\section{Author details}

'Department of Plant Protection and Biological Sciences, High Agronomic Institute of Chott-Mariem, University of Sousse, Sousse, Tunisia. ${ }^{2}$ Centre Technique des Dattes, Tozeur, Tunisia. ${ }^{3}$ Unidad Asociada de Entomología IVIA-CIB CSIC, Centro de Protección Vegetal y Biotecnología, InstitutoValenciano de Investigaciones Agrarias (IVIA), Ctra. Moncada a Naquea km 4.5, 46113 Moncada, Spain.

Received: 21 November 2019 Accepted: 9 March 2020

Published online: 18 March 2020

\section{References}

Ayvaz A, Karasu E, Karasu E, Karaborklu S, Tunçbilek AS (2008) Effects of cold storage, rearing temperature, parasitoid age and irradiation on the performance of Trichogramma evanescens Westwood (Hymenoptera: Trichogrammatidae). J Stored Prod Res 44:232-240

Bradley JR, Thomson $L$, Hoffmann AA (2004) Effects of cold storage on field and laboratory performance of Trichogramma carverae (Hymenoptera: Trichogrammatidae) and the response of three Trichogramma spp. (T. carverae, T. nr. brassicae, and T. funiculatum) to cold. J Econ Entomol 97:213-221

Colinet H, Boivin G (2011) Insect parasitoids cold storage: a comprehensive review of factors of variability and consequences. Biol Control 58:83-95

Core Team R (2019) R: a language and environment for statistical computing. R Foundation for Statistical Computing, Vienna, Austria https:/www.R-project.org/

Greenberg SM, Nordund DA, King EG (1996) Mass production of Trichogramma spp.: experience in the former Soviet Union, China, United States and Western Europe. Biocontrol News Inform 17(3):51-60

Hassan SA (1993) The mass rearing and utilization of Trichogramma to control lepidopterous pests: achievements and outlook. Pestic Sci 37(4):387-391

Herz A, Hassan SA, Hegazi E, Khafagi WE, Nasr FN, Youssef Al, Agamy E, Blibech I, Ksentini I, Ksantini M, Jardak T, Bento A, Pereira JA, Torres L, Souliotis C, Moschos T, Panos M (2007) Egg parasitoids of the genus Trichogramma (Hymenoptera, Trichogrammatidae) in olive groves of the Mediterranean region. Biol Control 40:48-56

Jalali SK, Singh SP (1992) Differential response of four Trichogramma species to low temperatures for short term storage. Entomophaga 37:159-165
Kumar P, Shenhmar M, Brar KS (2005) Effect of low temperature storage on the efficiency of three species of trichogrammatids. J Biol Cont 19:17-21

Leopold RA (1998) Cold storage of insects for integrated pest management. In: Hallman GJ, Denlinger DL (eds) Temperature Sensitivity in Insects and Application in Integrated Pest Management. Westview Press, Boulder, CO, pp 235-267

Li LY (1994) Worldwide use of Trichogramma for biological control on different crops: a survey. In: Wajnberg E, Hassan SA (eds) Biological Control with Egg Parasitoids. CAB International, Wallingford, UK, pp 37-53

Lü X, Han S, Li J, Liu J, Li Z (2019) Effects of cold storage on the quality of Trichogramma dendrolimi Matsumura (Hymenoptera: Trichogrammatidae) reared on artificial medium. Pest Manag Sci 75:1328-1338

$\mathrm{Ma}$ CS, Chen YW (2006) Effects of constant temperature, exposure period, and age on diapause induction in Trichogramma dendrolimi. Bio Control 36:267-273

Ozder N, Saglam O (2004) Effect of short-term cold storage on the quality of Trichogramma brassicae, T. cacoeciae, and T. evanescens (Hymenoptera: Trichogrammatidae). Great Lakes Entomol 37:183-187

Piao YF, Lin H, Shi GR (1992) Quality control of the physique of mass-reared Trichogramma. Plant Prot 18:28-29

Pitcher SA, Hoffmann MP, Gardner J, Wright MG, Kuhar TP (2002) Cold storage of Trichogramma ostriniae reared on Sitotroga cerealella eggs. Bio Control 47: $525-535$

Pizzol J (1978) La diapause chez Trichogramma evanescens Westwood (Hym., Trichogrammatidae), écotype moldave parasite oophage de la Pyrale du maïs. Diplôme, de l'Ecole Pratique des Hautes Etudes. Institut de Montpellier, 78 pp.

Pizzol J, Pintureau B, Khoualdia O, Desneux N (2010) Temperature dependent differences in biological traits between two strains of Trichogramma cacoeciae (Hym. Trichogrammatidae). J Pest Sci 83:447-452

Siam A, Zohdy NZM, ELHafez AMA, Moursy LE, Sherif HAEL (2019) Effect of different cold storage periods of rearing host eggs on the performance of the parasitoid Trichogramma evanescens (Westwood) (Hymenoptera: Trichogrammatidae). Egypt J Biol Pest Control 29(34):1-4

Tezze AA, Botto EN (2004) Effect of cold storage on the quality of Trichogramma nerudai (Hymenoptera: Trichogrammatidae). Biol Control 30:11-16

Ventura Garcia P, Wajnberg E, Pizzol J, Oliveira MLM (2002) Diapause in the egg parasitoid Trichogramma cordubensis: role of temperature. J. Insect Physiol 48:349-355

\section{Publisher's Note}

Springer Nature remains neutral with regard to jurisdictional claims in published maps and institutional affiliations.

\section{Submit your manuscript to a SpringerOpen ${ }^{\circ}$ journal and benefit from:}

- Convenient online submission

- Rigorous peer review

- Open access: articles freely available online

High visibility within the field

- Retaining the copyright to your article

Submit your next manuscript at $\boldsymbol{\nabla}$ springeropen.com 